\begin{tabular}{|c|c|c|c|}
\hline \multirow{3}{*}{$\begin{array}{r}\text { Case Reports in } \\
\text { Gastroenterology }\end{array}$} & \multirow{2}{*}{\multicolumn{2}{|c|}{ Case Rep Gastroenterol 2016;10:685-692 }} & \multirow[b]{3}{*}{$\begin{array}{l}\text { Karger } \\
\text { Open access }\end{array}$} \\
\hline & & & \\
\hline & $\begin{array}{l}\text { DOI: 10.1159/000452654 } \\
\text { Published onlıne: November 14, } 2016\end{array}$ & $\begin{array}{l}\text { (C) } 2016 \text { The Author(s) } \\
\text { Published by S. Karger AG, Basel } \\
\text { www.karger.com/crg }\end{array}$ & \\
\hline & $\begin{array}{l}\text { This article is licensed under the } \mathrm{Cr} \\
\text { International License (CC BY-NC) (ht } \\
\text { Usage and distribution for commercial }\end{array}$ & $\begin{array}{l}\text { mons Attribution-NonCommercial } 4.0 \\
\text { rger.com/Services/OpenAccessLicense). } \\
\text { quires written permission. }\end{array}$ & \\
\hline
\end{tabular}

\title{
Possible Noninvasive Biomarker of Eosinophilic Esophagitis: Clinical and Experimental Evidence
}

\author{
Sathisha Upparahalli Venkateshaiah ${ }^{a} \quad$ Murli Manohar $^{\mathrm{a}} \quad$ Alok K. Verma $^{\mathrm{a}}$ \\ Uwe Blecker $^{\mathrm{b}} \quad$ Anil Mishra ${ }^{\mathrm{a}}$ \\ a Department of Medicine, Tulane Eosinophilic Disorders Center (TEDC), Section of \\ Pulmonary Diseases, New Orleans, LA, USA; ${ }^{b}$ Section of Pediatric Gastroentrology, \\ Tulane University, School of Medicine, New Orleans, LA, USA
}

\section{Keywords}

Eosinophilic esophagitis · Noninvasive Biomarker · CD274 (PDL1)

\begin{abstract}
Eosinophilic esophagitis (EoE) diagnosis and follow-up response to therapy is based on repeated endoscopies and histological examination for eosinophils/HPF. The procedure is invasive and risky in particular for the pediatric population. Presently, there is no highly sensitive and specific noninvasive blood test available to monitor the disease pathogenesis. Reports indicate the expression of PDL1 (CD274) on the eosinophils in allergic patients. Herein, we report that CD274-expressing and -nonexpressing eosinophils were detected in both examined pediatric and adult EoE patients. We show that CD274 expression on blood eosinophils and blood mRNA expression levels increase in the blood of EoE patients and decrease following treatment. These observations are consistent with the esophageal eosinophilia of before and after treatment in both examined patients. These two clinical and experimental analysis reports provide the possibility that the CD274 mRNA and CD274-expressing eosinophil levels may be novel possible noninvasive biomarkers for EoE.
\end{abstract}

(C) 2016 The Author(s)

Published by S. Karger AG, Basel 


\section{Case Reports in \\ Gastroenterology}

Case Rep Gastroenterol 2016;10:685-692

\begin{tabular}{l|l|}
\hline DOI: $10.1159 / 000452654$ & $\odot 2016$ The Author(s). Published by S. Karger AG, Basel \\
\hline
\end{tabular} www.karger.com/crg

Venkateshaiah et al.: Possible Noninvasive Biomarker of Eosinophilic Esophagitis: Clinical and Experimental Evidence

\section{Introduction}

Eosinophilic esophagitis (EoE) is an allergen-induced T cell-mediated disease and is differentiated from reflux esophagitis (GERD) by the magnitude of mucosal eosinophilia, presence of intraepithelial eosinophils and epithelial cell hyperplasia, and the lack of response to acid suppression $[1,2]$. EoE is an emerging entity throughout the world, as documented by recent case series from developed countries [3-12]. Despite the increased incidence of EoE, there is no novel noninvasive diagnosis of the disease that differentiates EoE from GERD. The NIH PubMed review indicates that approximately 26 studies are published in between 2006 and 2014 that propose a number of molecules as biomarkers from tissue biopsies and serum samples of EoE and non-EoE patients [13]. These molecules include eosinophilderived neurotoxin, eotaxin-1, eotaxin-2, eotaxin-3, interleukin-5 (IL)-5, IL-6, IL-9, IL-13, eosinophil peroxidase, absolute eosinophil count, mast cells, TSLP, tumor necrosis factor including transcripts of KBP51, and microRNAs 21 and 223 [13-21]. Interestingly, no difference in the predicted biomarker levels before and after treatment was validated as reliable noninvasive biomarker for the EoE [21]. Still, after two decades of investigation, EoE diagnostic criteria are based on biopsy eosinophil count ( $>15$ eosinophils/high-power field, HPF), upon at least 6 weeks of adequate dosages of proton pump inhibitors to block gastric acid secretion [22]. An expert panel established as part of the First International Group of EoE Researchers (FIGERS) recommends this criterion of diagnosis [23]. Thus, there is an urgent need to continue with innovative fundamental studies to uncover new possibilities for diagnostic and therapeutic interventions. More recently, CD274 expression was implicated on eosinophils and its role in allergic diseases [24-26] and we recently observed that human blood has both CD274 expressing (CD274+') and not expressing (CD274-) eosinophils in normal individuals and EoE patients. Herein, we present the case reports of one pediatric and one adult EoE patients that show induced PDL1 (CD274)-expressing eosinophils and induced PDL1 mRNA levels, which reduces to the normal level following the treatment. The observation of our current two EoE patients indicates that CD274 may be a novel molecule for monitoring EoE following treatment. These findings have to be established and need attention from health care providers to monitor this preliminary observation in large patient populations.

\section{Methods}

\section{Flow Cytometer Analysis}

Patients' blood eosinophils were analyzed as per the approved IRB protocol. The total blood cells were examined after staining with anti-CCR3, anti-Siglec-8, and anti-CD274 antibodies. $2 \times 10^{5}$ events of Siglec- 8 and CCR3 double positive eosinophils were gated to identify CD274-expressing or -nonexpressing eosinophil populations in the patient's blood. Data were acquired with a BD FACSCalibur flow cytometer (BD Biosciences) and analyzed with FlowJo software version 7.1 (Tree Star).

\section{Real-Time PCR Analysis}

The blood RNA was extracted using Trizol reagent (Invitrogen) following the manufacturer's protocol. The precipitated RNA was harvested by centrifugation, washed in $70 \%$ ethanol, dried, and suspended in sterile diethyl pyrocarbonate (DEPC)-treated water. RNA $(2 \mu \mathrm{g})$ prepared as described was subjected to DNase I treatment (Invitrogen) and reverse 
transcribed using a First Strand cDNA Synthesis Kit for RT-PCR (avian myeloblastosis virus reverse transcriptase; Roche Diagnostics). cDNA (1 $\mu \mathrm{L})$ was subjected to TaqMan (Q) PCR using a FAM-labeled probe and CD274 primers. No-reverse transcriptase and no-template controls were used and mouse GAPDH was used as the endogenous control. Transcripts at each time point were normalized to GAPDH. Values were expressed in relative expression (fold change). The primers that were used in the study were CD274: F-5'-CAT TTG CTG AAC GCC CCA TA-3'; R-5'-TCT TGG AAT TGG TGG TGG TG-3' , and GAPDH: F-5'-TGC ACC ACC AAC TGC TTA-3'; R-5'-GGA TGC AGG GAT GAT GTT C-3'.

\section{Results}

We report clinical histories and blood eosinophil analysis of one pediatric and one adult patient, which indicates CD274 (PDL1)-expressing and -nonexpressing eosinophils with a significant increase in the fraction of CD274-expressing eosinophils. Herein, we present the details of both patients' clinical characteristic and blood analysis.

\section{Pediatric Patient}

An 18-month-old female patient with vomiting and reflux came to the Tulane Hospital Clinic. She had no previous history of any allergic and family histories of atopic diseases. Laboratory testing showed a white blood count of $6.3 \times 10^{3} / \mu \mathrm{L}$ with $10 \%$ eosinophils (absolute eosinophils $0.63 \times 10^{3} / \mu \mathrm{L}$ ). The upper gastrointestinal tract endoscopy detected abnormal esophageal surface including redness and friability in the distal half of the esophagus. We examined proximal and distal esophagus biopsies for tissue eosinophilia and observed heavy eosinophilic infiltration in the esophageal mucosa. The eosinophil level in the esophageal biopsy was 100 eosinophils/HPF. Therefore, based on clinical characteristics and endoscopic and histological biopsy evaluation, the patient was diagnosed as EoE. The 18-month-old female patient was on complete avoidance of milk, egg, and soy with Gastrocrom and Omeprazole for 3 months, which showed significant improvement on clinical symptoms. The clinical improvement was further confirmed by repeat histological esophageal biopsy evaluation. The eosinophil level in the biopsy was found significantly decreased $(\sim 30-32$ eosinophils/HPF), which indicated the patient responded to the treatment. Since then, a recent report indicated that the eosinophils of asthma patients express CD274 [24]; therefore, we examined the expression of CD274 in the blood eosinophils of both patients. Herein, we report that our blood eosinophil analysis detected CD274+ and CD274- eosinophils in the blood of the patients (Fig. 1D). The CD274-expressing blood eosinophils were $45 \%$ before the treatment, which significantly decreased to $20 \%$ after the treatment (Fig. 1E). Further, we also found that the relative expression of CD274 mRNA level in the blood also decreased $\sim 3$-fold following treatment (Fig. 1F).

\section{Adult Patient}

Second, we report a similar observation in an adult 20-year-old male patient, who came to our faculty with dysphagia, swallowing difficulty, and food impaction. He has no family history of atopic disease like asthma. Laboratory testing showed white blood count $15.8 \times$ $10^{3} / \mu \mathrm{L}$ with $12 \%$ eosinophil (absolute eosinophils $1.85 \times 10^{3} / \mu \mathrm{L}$ ). Upper gastrointestinal tract endoscopy detected abnormal esophageal surface including longitudinal furrows. The eosinophil level in the esophageal biopsy was 100-130 eosinophils/HPF; therefore, based on clinical characteristics, endoscopic findings, and histological biopsy evaluation, the pa- 


\section{Case Reports in \\ Gastroenterology}

Case Rep Gastroenterol 2016;10:685-692

\begin{tabular}{l|l|}
\hline DOI: $10.1159 / 000452654$ & $\odot 2016$ The Author(s). Published by S. Karger AG, Basel \\
\hline
\end{tabular} www.karger.com/crg

Venkateshaiah et al.: Possible Noninvasive Biomarker of Eosinophilic Esophagitis: Clinical and Experimental Evidence

tient was diagnosed with EoE. Further, we treated the patient on avoidance of beef, pork, egg, peanut, milk, and tomato and Plumicort for 6 months, which showed significant improvement in the patient's clinical symptoms. The improvement of the disease was further confirmed by the evaluation of repeat histological biopsies. The eosinophil levels in the biopsy of this patient showed a significantly decreased level of $\sim 20-25$ eosinophils/HPF. Interestingly, like the pediatric patient, this adult patient also showed CD274 (PDL1)-expressing and -nonexpressing eosinophils in the blood (Fig. 2D). The fraction of CD274-expressing blood eosinophils was $75 \%$ pre-treatment and this significantly decreases to $23 \%$ after the treatment (Fig. 2E). Further, we also found that the relative expression of CD274 mRNA in the blood also decreased $\sim 8$-fold following treatment (Fig. 2F).

\section{Discussion}

The programmed death-ligand 1 (PDL1) is a 40-kDa type 1 transmembrane protein that has been speculated to play a major role in suppressing the immune system during particular events such as pregnancy, tissue allografts, and autoimmune disease as well as allergic diseases [24, 27-30]. PDL1 is also recognized as an activation and maturation marker of T cells [31,32]. The increased number of PDL1 (CD274)-expressing blood eosinophils in both reported pediatric and adult EoE patients indicates that $\mathrm{CD} 274^{+}$eosinophils may be more mature, activated eosinophils that following successful treatment decrease in parallel with both patients' improved EoE. The increase in CD274-expressing eosinophils is consistent with the increased blood mRNA relative expression of CD274 (PDL1) in both patients followed by significant decrease following the treatment. Notably, the increased fraction of CD274 mRNA expression and CD274 eosinophils is consistent in the patients. The adult 20year-old patient showed a much larger fraction of CD274-expressing eosinophils and higher mRNA levels compared to the 18-month-old pediatric patient, which shows the significance of CD274 expression for the chronic disease pathogenesis. Both EoE patient case studies and their blood eosinophil analysis for the first time show a strong relation between CD274 expression on eosinophils and histological esophageal biopsy findings. EoE is a new entity with no reliable noninvasive diagnostic tools to help clinicians differentiate EoE from other conditions like GERD. Blood tests are not used for EoE diagnosis; however, these two case reports and their blood analysis for the first time indicate that blood test may be useful for the diagnosis of EoE. Taken together, both case reports indicate that pre- and post-treatment analysis of blood CD274 mRNA levels as well as the fraction of CD274+ eosinophils may be a predictive possible noninvasive biomarker for EoE and needs detailed investigation in a large population of established reliable noninvasive biomarker for human EoE.

\section{Acknowledgements}

This work was supported in part by the grants NIH R01 AI080581 (A.M.). We thank Christine Glynn, RN, and the research coordinators for their efforts in IRB approval and enrolling the patients, collecting the samples, and recording and providing the patients characteristics. 
Venkateshaiah et al.: Possible Noninvasive Biomarker of Eosinophilic Esophagitis: Clinical and Experimental Evidence

\section{Authors' Contributions}

Sathisha Upparahalli Venkateshaiah, flow cytometer data acquisition and analysis. Murli Manohar, blood mRNA isolation and PCR analysis. Alok K. Verma, blood ELISA analysis. Uwe Blecker, patients' characteristics, endoscopic evaluation, tissue provided for analysis. Anil Mishra, study design and draft including manuscript writing and data interpretation.

\section{Statement of Ethics} findings.

The patients' consent was taken to use tissue samples for investigation and report the

\section{Disclosure Statement}

No author has any financial interest or conflict of interest.

\section{References}

1 Furuta GT, Liacouras CA, Collins MH, Gupta SK, Justinich C, Putnam PE, Bonis P, Hassall E, Straumann A, Rothenberg ME: Eosinophilic esophagitis in children and adults: a systematic review and consensus recommendations for diagnosis and treatment. Gastroenterology 2007;133:1342-1363.

-2 Rothenberg ME, Mishra A, Collins MH, Putnam PE: Pathogenesis and clinical features of eosinophilic esophagitis. J Allergy Clin Immunol 2001;108:891-894.

-3 Croese J, Fairley SK, Masson JW, Chong AK, Whitaker DA, Kanowski PA, Walker NI: Clinical and endoscopic features of eosinophilic esophagitis in adults. Gastrointest Endosc 2003;58:516-522.

4 Cury EK, Schraibman V, Faintuch S: Eosinophilic infiltration of the esophagus: gastroesophageal reflux versus eosinophilic esophagitis in children - discussion on daily practice. J Pediatr Surg 2004;39:e4-e7.

-5 Attwood SE, Smyrk TC, Demeester TR, Jones JB: Esophageal eosinophilia with dysphagia. A distinct clinicopathologic syndrome. Dig Dis Sci 1993;38:109-116.

6 Cantu P, Velio P, Prada A, Penagini R: Ringed oesophagus and idiopathic eosinophilic oesophagitis in adults: an association in two cases. Dig Liver Dis 2005;37:129-134.

-7 Fujiwara H, Morita A, Kobayashi H, Hamano K, Fujiwara Y, Hirai K, Yano M, Naka T, Saeki Y: Infiltrating eosinophils and eotaxin: their association with idiopathic eosinophilic esophagitis. Ann Allergy Asthma Immunol 2002;89:429-432.

-8 Munitiz V, Martinez de Haro LF, Ortiz A, Pons JA, Bermejo J, Serrano A, Molina J, Parrilla P: Primary eosinophilic esophagitis. Dis Esophagus 2003;16:165-168.

-9 Lucendo AJ, Carrion G, Navarro M, Pascual JM, Gonzalez P, Castillo P, Erdozain JC: Eosinophilic esophagitis in adults: an emerging disease. Dig Dis Sci 2004;49:1884-1888.

-10 Straumann A, Spichtin HP, Bucher KA, Heer P, Simon HU: Eosinophilic esophagitis: red on microscopy, white on endoscopy. Digestion 2004;70:109-116.

$\$ 11$ Straumann A: What is your diagnosis? Primary eosinophilic esophagitis (in German). Praxis (Bern 1994) 2004;93:795-796.

12 Orenstein SR, Shalaby TM, Di Lorenzo C, Putnam PE, Sigurdsson L, Kocoshis SA: The spectrum of pediatric eosinophilic esophagitis beyond infancy: a clinical series of 30 children. Am J Gastroenterol 2000;95:1422-1430.

13 Bhardwaj N, and Ghaffari G: Biomarkers for eosinophilic esophagitis: a review. Ann Allergy Asthma Immunol 2012;109:155-159.

14 Dellon ES, Chen X, Miller CR, Woosley JT, Shaheen NJ: Diagnostic utility of major basic protein, eotaxin3 , and leukotriene enzyme staining in eosinophilic esophagitis. Am J Gastroenterol 2012;107:15031511.

15 Bhattacharya B, Carlsten J, Sabo E, Kethu S, Meitner P, Tavares R, Jakate S, Mangray S, Aswad B, Resnick MB: Increased expression of eotaxin-3 distinguishes between eosinophilic esophagitis and gastroesophageal reflux disease. Hum Pathol 2007;38:1744-1753. 


\section{Case Reports in \\ Gastroenterology}

Case Rep Gastroenterol 2016;10:685-692 DOI: $10.1159 / 000452654$

(c) 2016 The Author(s). Published by S. Karger AG, Basel www.karger.com/crg

Venkateshaiah et al: Possible Noninvasive Biomarker of Eosinophilic Esophagitis: Clinical and Experimental Evidence

-16 Subbarao G, Rosenman MB, Ohnuki L, Georgelas A, Davis M, Fitzgerald JF, Molleston JP, Croffie JM, Pfefferkorn MD, Corkins MR, et al: Exploring potential noninvasive biomarkers in eosinophilic esophagitis in children. J Pediatr Gastroenterol Nutr 2011;53:651-658.

-17 Lu TX, Sherrill JD, Wen T, Plassard AJ, Besse JA, Abonia JP, Franciosi JP, Putnam PE, Eby M, Martin LJ, et al: MicroRNA signature in patients with eosinophilic esophagitis, reversibility with glucocorticoids, and assessment as disease biomarkers. J Allergy Clin Immunol 2012;129:1064-1075.e9.

18 Lucendo AJ, De Rezende L, Comas C, Caballero T, Bellon T: Treatment with topical steroids downregulates IL-5, eotaxin-1/CCL11, and eotaxin-3/CCL26 gene expression in eosinophilic esophagitis. Am J Gastroenterol 2008;103:2184-2193.

19 Dellon ES, Aderoju A, Woosley JT, Sandler RS, Shaheen NJ: Variability in diagnostic criteria for eosinophilic esophagitis: a systematic review. Am J Gastroenterol 2007;102:2300-2313.

20 Dellon ES, Chen X, Miller CR, Fritchie KJ, Rubinas TC, Woosley JT, Shaheen NJ: Tryptase staining of mast cells may differentiate eosinophilic esophagitis from gastroesophageal reflux disease. Am J Gastroenterol 2011;106:264-271.

-21 Dellon ES, Rusin S, Gebhart JH, Covey S, Higgins LL, Beitia R, Speck O, Woodward K, Woosley JT, Shaheen NJ: Utility of a Noninvasive Serum Biomarker Panel for Diagnosis and Monitoring of Eosinophilic Esophagitis: A Prospective Study. Am J Gastroenterol 2015;110:821-827.

22 Liacouras CA, Furuta GT, Hirano I, Atkins D, Attwood SE, Bonis PA, Burks AW, Chehade M, Collins MH, Dellon ES, et al: Eosinophilic esophagitis: updated consensus recommendations for children and adults. J Allergy Clin Immunol 2011;128:3-20.e6; quiz 21-22.

-23 Liacouras CA, Bonis P, Putnam PE, Straumann A, Ruchelli E, Gupta SK, Lee JJ, Hogan SP, Wershil BK, Rothenberg ME, et al: Summary of the First International Gastrointestinal Eosinophil Research Symposium. J Pediatr Gastroenterol Nutr 2007;45:370-391.

24 Tak T, Hilvering B, Tesselaar K, Koenderman L: Similar activation state of neutrophils in sputum of asthma patients irrespective of sputum eosinophilia. Clin Exp Immunol 2015;182:204-212.

-25 Akbari O, Stock P, Singh AK, Lombardi V, Lee WL, Freeman GJ, Sharpe AH, Umetsu DT, Dekruyff RH: PDL1 and PD-L2 modulate airway inflammation and iNKT-cell-dependent airway hyperreactivity in opposing directions. Mucosal Immunol 2010;3:81-91.

-26 Singh AK, Stock P, Akbari O: Role of PD-L1 and PD-L2 in allergic diseases and asthma. Allergy 2011;66:155-162.

27 Richards CJ, Hsu D, Weinstock TG, Clardy P: Eosinophils. An unexpected delivery. Ann Am Thorac Soc 2013;10:390-392.

-28 Amdur HS, Levin RE: Eosinophilic fasciitis during pregnancy. Obstet Gynecol 1989;73:843-847.

29 Ten RM, Gleich GJ, Holley KE, Perkins JD, Torres VE: Eosinophil granule major basic protein in acute renal allograft rejection. Transplantation 1989;47:959-63.

-30 Hongwei W, Nanra RS, Stein A, Avis L, Price A, Hibberd AD: Eosinophils in acute renal allograft rejection. Transpl Immunol 1994;2:41-46.

-31 Zhang Y, Chung Y, Bishop C, Daugherty B, Chute H, Holst P, Kurahara C, Lott F, Sun N, Welcher AA, et al: Regulation of T cell activation and tolerance by PDL2. Proc Natl Acad Sci USA 2006;103:11695-11700.

-32 Chen N, Fang W, Zhan J, Hong S, Tang Y, Kang S, Zhang Y, He X, Zhou T, Qin T, et al: Upregulation of PDL1 by EGFR activation mediates the immune escape in EGFR-driven NSCLC: implication for optional immune targeted therapy for NSCLC patients with EGFR mutation. J Thorac Oncol 2015;10:910-923. 

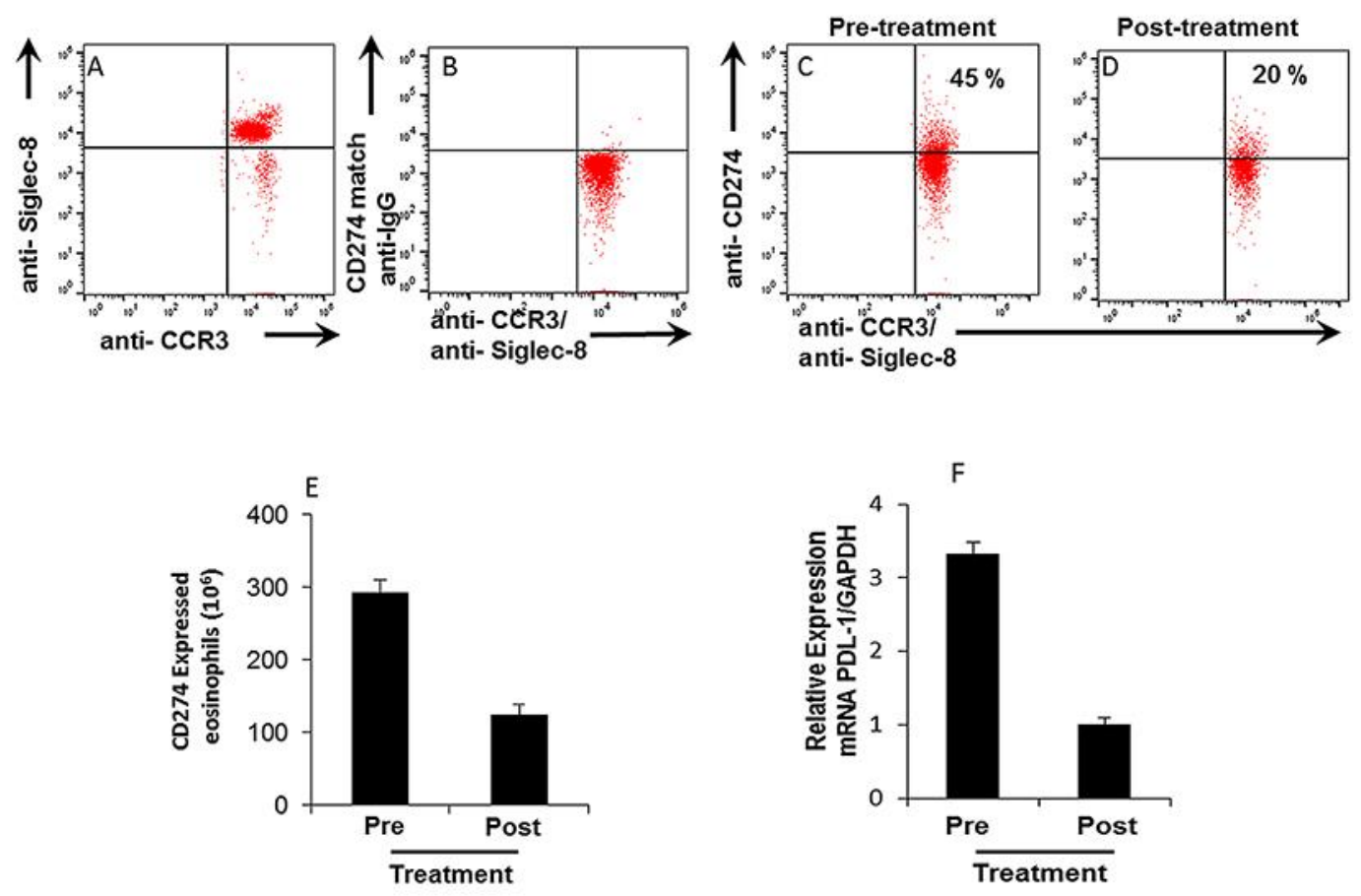

Fig. 1. CD274 expression in the blood of the pediatric EoE patient. A representative flow cytometer dot blot analysis shows anti-CCR3 and anti-Siglec-8 double positive eosinophils in the blood (A), expression of CD274 on blood eosinophils pre-treatment (B) and post-treatment (C), and anti-CD274 matched IgG isotype on CCR3 and Siglec-8 double positive eosinophils (D). The quantitative absolute number of CD274expressing eosinophils (E) and PCR analysis of the relative expression of CD274 mRNA levels (F) in the blood of the pediatric EoE patient pre- and post-treatment. 
Venkateshaiah et al.: Possible Noninvasive Biomarker of Eosinophilic Esophagitis: Clinical and Experimental Evidence
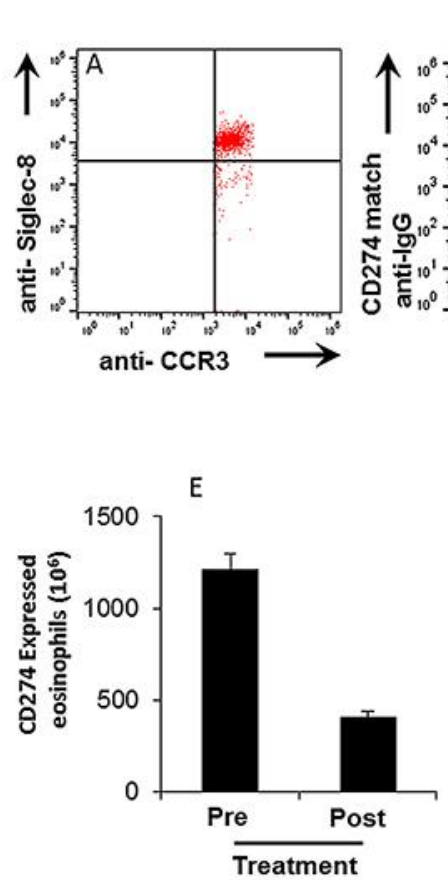
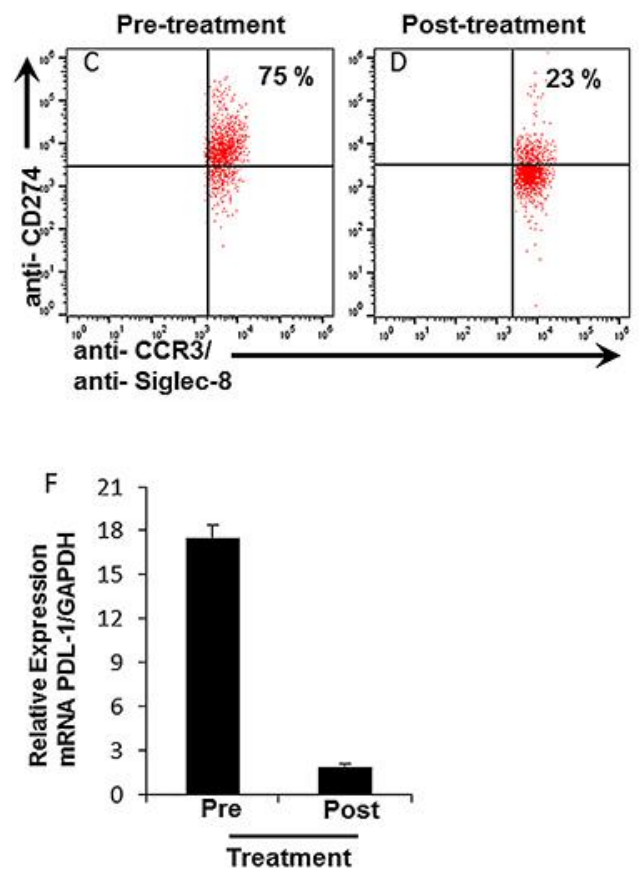

Fig. 2. CD274 expression in the blood of the adult EoE patient. A representative flow cytometer dot blot analysis shows anti-CCR3 and anti-Siglec-8 double positive eosinophils in the blood (A), expression of CD274 on blood eosinophils pre-treatment (B) and post-treatment (C), and anti-CD274 matched IgG isotype on CCR3 and Siglec-8 double positive eosinophils (D). The quantitative absolute number of CD274expressing eosinophils (E) and PCR analysis of the relative expression of CD274 mRNA levels (F) in the blood of the adult EoE patient pre- and post-treatment. 